\title{
Students Responses To Plagiarism Thesis Making (Study at Law Faculty of Muhammadiyah University of North Sumatera)
}

\author{
Ramlan, Nurul Hakim, Tengku Erwinsyah bana \\ Lecturers at Law Faculty of Muhammadiyah University of North Sumatera
}

\begin{abstract}
The purpose of this study was to analyze the responses and views of law students against plagiarism behavior that is quite common among college students, and motivation that led to the behavior of plagiarism rife among students, as well as regulations on plagiarism. The experiment was conducted using reseacrh and development models and methods of the survey, with quantitative and qualitative approaches. Data retrieved through the instrument and interviews, as well as the source of data is the students of the Faculty of Law, University of North Sumatra Muhammadiyah, with the number of respondents 600 semester students 8. The results show that: the behavior of plagiarism among students have an average to agree 36\%; motivation plagiarism among students, has an average for the category agree 27\%; media socialization early prevention of plagiarism had average for the category agree 48\%. Internally the occurrence of plagiarism because laziness, stress, fear of failure, pessimism, the view that the act of plagiarism is not a thing wrong, and feel such actions are not known to others. Externally plagiarism occurred because the institutions are not firm, and fear of negative image on the institutions.
\end{abstract}

Keywords: Students Respon, Thesis Making, plagiarism.

\section{BACKGROUND}

One of the most important components and is a barometer of Tri Dharma college success is the ability of students. Students are "intellectual community has a keen analytical power in capturing the social and natural phenomena comprehensively (Ali, 2000: 85). In an institution of higher education students are the most important component, because most of the academic and non-academic will ultimately be measured by how much the quality of teaching and the quality of students who called quality graduates and reliable, which is a requirement of graduation for students is the thesis-making.

But unfortunately at the moment a lot of students in making paper as the final project is done in ways that are not justified, as the behavior of falsification, fabrication and plagiarism, which seemed to be a normal thing to do just now. In fact, one of the highest grade paper is the originality or authenticity. The statement implies, that a paper should have a quality value in terms of authenticity, objectivity, and honesty.Meaning of 'authentic' to a paper that does not mean all ideas, ideas, and knowledge that a person delivered all from himself. But rather on honesty in expressing his writing. If a word, sentence, paragraph, ideas, ideas or opinions that appear in his work is the property of another person (or from another source), then the scientific ethic is to include resources honestly and objectively where he was getting these quotes. So cases of duplication, copying, or plagiarism emerged, precisely because the values of honesty and objectivity are violated or ignored.The results of a student's success in the midst of the community would be, not only reliable with scholarship, but there are important factors that determine and provide a very meaningful contribution to the future of their future is honesty (Tilaar, 1998: 372).

Honesty or scientific originality in terms of papers included in the frame of character building. That is, the academic community residents should always keep the spirit of developing the value and character (Ismail, 2006: 4). If this value is missing, or faded, it is not necessarily the quality of humanity, especially in the campus also will disappear. In fact, the Minister of National Education, Muhammad Nuh said, "rampant acts of plagiarism shows the weakness of character education, cultural, and moral person in the academic world" (Rachmat, 2010: 15). Dispositions and attitudes contained in grains of academic-scientific ethics which must be upheld is an honest and objective in scienctific life (Ethics of Students and Lecturers UNY, 2005).Observing these circumstances, it can be seen that with regard to improving the quality of graduation with a capital honesty there are some problems. However, to obtain the actual results and in accordance with the real situation, should be carried out related research with a view to the student of law faculty thesis plagiarist rampant among students, who performed at the Faculty of Law, University of North Sumatra Muhammadiyah.

Echols and Shadily (1983: 132) translates plagiarism as copying, plagiarism. The culprit is called cheater, plagiarist. Heffernan and Lincoln (1986: 522) explains that; "Plagiarism is the dishonest of presenting the words or thoughts of another writer as if they were your own. You commit plagiarism whenever you use a source in any way without Indicating that you have used it ". While Brotowidjoyo (1993: 86) explains that: 
Plagiarism is the result of piracy or the use of sampling in the form of facts, explanations, phrases, and sentences of others unlawfully. The result of piracy, kidnapping, and use of facts, phrases, and so such unauthorized called plagiarism.

Further Brotowidjoyo (1993: 86-87) explains that "... as well as real estate owned by individuals, the idea or new facts were found or collected, explanations, phrases, words are owned by individuals who are recognized and protected by Constitution". "Therefore, if you use it in your article, then you are obliged to admit that you borrow from others". "If you do not declare or pretend not to know about it, then your actions categorized as plagiarism and violations of the law".

Utorodewo et al., (2007) classified several things including plagiarism action, namely:

1. Acknowledge the writings of others as his own writings;

2. Acknowledge the ideas of others as our own thoughts;

3. Acknowledging the findings of others as belonging to themselves;

4. Recognizing the work as belonging to the group or its own results;

5. Presenting the same article on different occasions without mentioning the originator;

6. Summarizing and paraphrasing (not direct quote) without citing sources; and

7. Summarizing and paraphrasing by naming its sources, but a series of sentences and the choice of words is still too similar to its source.

As for the kind of plagiarism by Soelistyo (2011) there are a couple of things:

1. Plagiarism is word for word (Word for word Plagiarism). The author uses the words of other authors (exact) without citing sources.

2. Plagiarism on the source (Plagiarism of Source). The author uses the ideas of others without giving sufficient recognition (without naming its sources clearly).

3. Plagiarism authorship. The author recognizes as an author writing other people's work.

4. Self Plagiarism. Included in this type are authors published an article on more than one editorial publications, and recycle papers / scientific work.

According to Article 2 paragraph (1) of the Regulation of the Minister of National Education No. 17 of 2010 on the Prevention and Combating Plagiarism In Higher Education, determine plagiarism include but are not limited to:

1. Referring to and / or quotes terms, words and / or phrases, data and / or information from a source without citing a source in the notes quotations and / or without stating the source adequately;

2. Referring to and / or quotes randomly terms, words and / or phrases, data and / or information from a source without citing a source in the notes quotations and / or without stating the source adequately;

3. Using a source of ideas, opinions, views, or theory without stating the source adequately;

4. Formulate with words and / or phrases themselves from the source of words and / or phrases, ideas, opinions, views, or theory without stating the source adequately;

5. Submitting a scientific papers produced and / or published by others as his scientific work without stating the source adequately..

\section{RESEARCH METHOD}

This study was conducted using the Model reseacrh and development and the survey method (Juhanaini, 2010). The approach of this research is quantitative and descriptive qualitative, conducted to collect data and information about the views of student idealism against the rise of plagiarism among students. The subjects in this study were all students of 8th semester of Law Faculty, Muhammadiyah University of North Sumatra which numbering 600 people, from 13 classes. Samples were taken based on a purposive sample or sampling based on the destination (Sugiyono, 2009). It also used the interview to complete the data of the study.Data analysis was performed through the average count, the percentage by taking into account the results obtained from a questionnaire distributed. Further analysis supplemented with interviews to enhance research results.

\section{RESULTS AND DISCUSSION}

1. The students views of Law Faculty of Muhammadiyah University of North Sumatra against the rise of thesis plagiarists among students.

Plagiarism is a form of theft of ideas, data or findings, including those not yet published. There are five (5) the level of plagiarism, which is mostly found among students, which can be summarized from various views:

a. Copying (without acknowledgment) word-per-word of the entire article, or most of the writing, or copy word-per word in more than one article by the same author.

b. Copying (without acknowledgment) word-per-word portion or copy writing a word by word more than one article by the same author. 
c. Copying (without acknowledgment) word-per-word writing elements (paragraphs, sentences, ilustasi, etc.) Are on an important part of an article.

d. Copying with paraphrased incorrectly paragraph or a page without giving recognition.

e. Copying (by giving recognition) word-for-word most of the papers without giving delineation (quote or indent) is clear.

f. Repeating the paper itself, which has been published without mentioning as reference material is also one form of plagiarism, which is commonly called otoplagiasi (self plagiarism).

g. Taking an idea or ideas of others and present it in their own words.

From the questionnaire to students of sixth semester Department of Criminal Law, Civil Law, Constitutional Law and Administrative Law of Muhammadiyah University North Sumatra, the view can be summarized and their understanding of the concept of plagiarism, consisting of 1) the views of students about the behavior of plagiarism among students ,2) motivation that causes plagiarism among students, and 3) media.

\section{a. The View of Students about Behavior of Plagiarism}

Tabel 1: Plagiarism Component

\begin{tabular}{|l|l|l|}
\hline NO & Component & Item \\
\hline 1 & Acknowledging the work of others as his own & $1,6,7$ \\
\hline 2 & Citing ideas, words, paragraphs, paraphrasing others & $2,3,4,5,8$ \\
\hline 3 & Delivering the arguments of others with their own words & $9,10,11$ \\
\hline 4 & Fictitious data, the composition of data own without direct research & $12,13,14$ \\
\hline
\end{tabular}

Based on the table above, can be translated into 14 (fourteen) statement item. Statement questionnaire aims to explore the extent of the student's knowledge about the understanding, ethics, and elements of plagiarism. The results obtained are summarized in percentage $(\%)$ in the table below:

Tabel 2: Presentase Prilaku Plagiat Mahasiswa

\begin{tabular}{|c|c|c|c|c|c|c|}
\hline \multirow[t]{2}{*}{ NO } & \multirow[t]{2}{*}{ Statement of Plagiarism Behavior Among Students } & \multicolumn{5}{|c|}{ Percentage } \\
\hline & & SS & $\mathbf{S}$ & $\mathbf{R}$ & TS & STS \\
\hline 1 & $\begin{array}{l}\text { Presenting the work of others as his own property can be } \\
\text { categorized as plagiarism }\end{array}$ & 69 & 22 & 4 & 1 & 4 \\
\hline 2 & $\begin{array}{l}\text { Downloading material from Internet sources without } \\
\text { acknowledgment is called plagiarism }\end{array}$ & 43 & 33 & 11 & 8 & 5 \\
\hline 3 & $\begin{array}{l}\text { Using the ideas or words found on the Internet and text } \\
\text { sources without acknowledging the source from which it } \\
\text { originates is plagiarism }\end{array}$ & 32 & 47 & 9 & 7 & 5 \\
\hline 4 & $\begin{array}{l}\text { Forgot to add citations (references) on the citation called } \\
\text { plagiarism }\end{array}$ & 10 & 21 & 36 & 21 & 12 \\
\hline 5 & Taking other people's writing is plagiarism & 31 & 40 & 14 & 11 & 4 \\
\hline 6 & Copying the work of others is plagiarism & 38 & 41 & 14 & 6 & 1 \\
\hline 7 & $\begin{array}{l}\text { Taking the idea, summary, paraphrase or quote but } \\
\text { delivered with the sentence itself, including plagiarism }\end{array}$ & 7 & 21 & 12 & 48 & 12 \\
\hline 8 & $\begin{array}{l}\text { Copy the text from the website and paste it on one's own } \\
\text { writings without the quotation marks is called } \\
\text { plagiarism }\end{array}$ & 16 & 39 & 26 & 13 & 6 \\
\hline 9 & $\begin{array}{l}\text { Repeat or paraphrase the words of others without being } \\
\text { recognized categorized plagiarism }\end{array}$ & 16 & 49 & 21 & 9 & 5 \\
\hline 10 & $\begin{array}{l}\text { Repeating arguments person or another person's line of } \\
\text { thought, including plagiarism }\end{array}$ & 7 & 26 & 35 & 26 & 6 \\
\hline 11 & $\begin{array}{l}\text { Buying the results of research and used for the benefit of } \\
\text { its own is plagiarism }\end{array}$ & 37 & 38 & 10 & 13 & 2 \\
\hline 12 & $\begin{array}{l}\text { Created in the bibliography should be cited in the } \\
\text { composition }\end{array}$ & 39 & 37 & 17 & 7 & 0 \\
\hline 13 & $\begin{array}{l}\text { Making up the data itself (Fabrication) without jump } \\
\text { directly to the location of research is a kind of scientific } \\
\text { violation }\end{array}$ & 30 & 50 & 16 & 1 & 3 \\
\hline 14 & $\begin{array}{l}\text { Falsification of research data is a kind of scientific } \\
\text { violation }\end{array}$ & 9 & 46 & 40 & 4 & 1 \\
\hline
\end{tabular}

$\mathrm{SS}=$ Strongly Agree, $\mathrm{S}=$ Agree, $\mathrm{R}=$ Doubtful, $\mathrm{TS}=$ Disagree, $\mathrm{STS}=$ Strongly Disagree 
Based on the behavior of the statement table of plagiarism among students above the average value for the agreed $36 \%$.

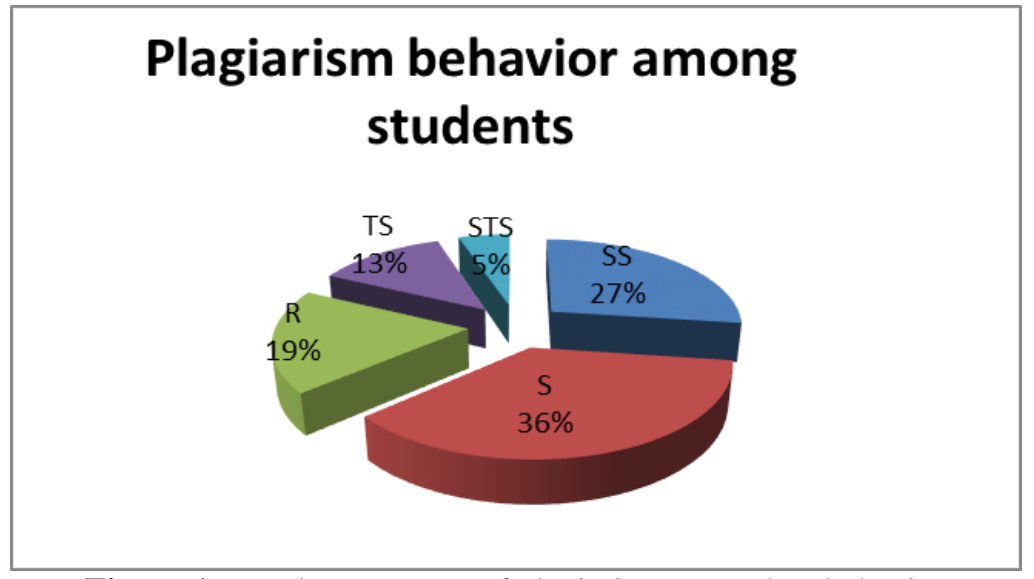

Figure 1. Results statement of plagiarism on student behavior

\section{b. Plagiarism motivation among Students}

Table 3: Plagiarism Motivation

\begin{tabular}{|l|l|l|}
\hline NO & Motivation Factor & Item \\
\hline 1 & Not confident & $1,3,7$ \\
\hline 2 & The high burden of tuition & 2,4 \\
\hline 3 & Lack of literature & 5 \\
\hline 4 & Lack of socialization & $6,8,9,10$ \\
\hline 5 & Problems of supervisor & 11.12 \\
\hline
\end{tabular}

Based on Table 3 above, it can be described in 12 items statement. The statement was formulated to determine the factors and the students motivate to do against scientific ethics or plagiarism. The results of the questionnaire distribution are as follows::

Tabel 4: Motivation of Plagiarism on Studnts (\%)

\begin{tabular}{|c|c|c|c|c|c|c|}
\hline \multirow[t]{2}{*}{ NO } & \multirow[t]{2}{*}{ Statement of Plagiarism Motivation Among Students } & \multicolumn{5}{|c|}{ Percentage } \\
\hline & & SS & $\mathbf{S}$ & $\mathbf{R}$ & TS & STS \\
\hline 1 & $\begin{array}{l}\text { I take, repeat, citing ideas, the ideas of others without } \\
\text { acknowledgment, because not sure of his/her own abilities }\end{array}$ & 13 & 20 & 30 & 30 & 7 \\
\hline 2 & $\begin{array}{l}\text { Many course load, as a trigger I download on the Internet } \\
\text { to complete the task }\end{array}$ & 20 & 39 & 13 & 24 & 4 \\
\hline 3 & $\begin{array}{l}\text { The lack of literature, an obstacle in completing } \\
\text { assignments }\end{array}$ & 22 & 38 & 20 & 16 & 4 \\
\hline 4 & $\begin{array}{l}\text { I am sure that assignments will not be checked one by one } \\
\text { by lecturer }\end{array}$ & 8 & 11 & 37 & 36 & 8 \\
\hline 5 & $\begin{array}{l}\text { Completed research data on the internet trigger me in } \\
\text { misusing personal data for any purpose }\end{array}$ & 9 & 34 & 21 & 27 & 9 \\
\hline 6 & $\begin{array}{l}\text { The absence of strict sanctions from the Faculty of } \\
\text { plagiarism becomes safe to do so }\end{array}$ & 27 & 25 & 22 & 21 & 5 \\
\hline 7 & $\begin{array}{l}\text { The lack of appreciation of the students who wrote in the } \\
\text { mass media, competitions, campus newspapers, makes me } \\
\text { not used to explore the ability to write }\end{array}$ & 20 & 36 & 15 & 23 & 6 \\
\hline 8 & $\begin{array}{l}\text { Restrictions and sanctions of plagiarism for a writing, } \\
\text { there are no rules of the Faculty }\end{array}$ & 12 & 38 & 21 & 21 & 8 \\
\hline 9 & $\begin{array}{l}\text { Socialization of plagiarism in the form of circulars and } \\
\text { meeting with students has never been held in the faculty }\end{array}$ & 21 & 36 & 20 & 17 & 6 \\
\hline 10 & $\begin{array}{l}\text { The absence of formal instructions regarding the } \\
\text { procedure of writing, quoting, repetition, ideas, } \\
\text { paragraphs, sentences, the property of others into their } \\
\text { own work by Faculty }\end{array}$ & 8 & 17 & 13 & 37 & 25 \\
\hline 11 & $\begin{array}{l}\text { Communication does not connect with the supervisor, be a } \\
\text { reason for me to imitate the work according to my title }\end{array}$ & 8 & 20 & 21 & 38 & 13 \\
\hline 12 & $\begin{array}{l}\text { Supervising by the Faculty is not in accordance with the } \\
\text { substance of my thesis }\end{array}$ & 7 & 22 & 41 & 25 & 5 \\
\hline
\end{tabular}

SS = Strongly Agree, $\mathrm{S}=$ Agree, R = Doubtful, TS = Disagree, STS = Strongly Disagree 
Based on the table a statement of motivation plagiarism among students, the average value for the category agree is $27 \%$.

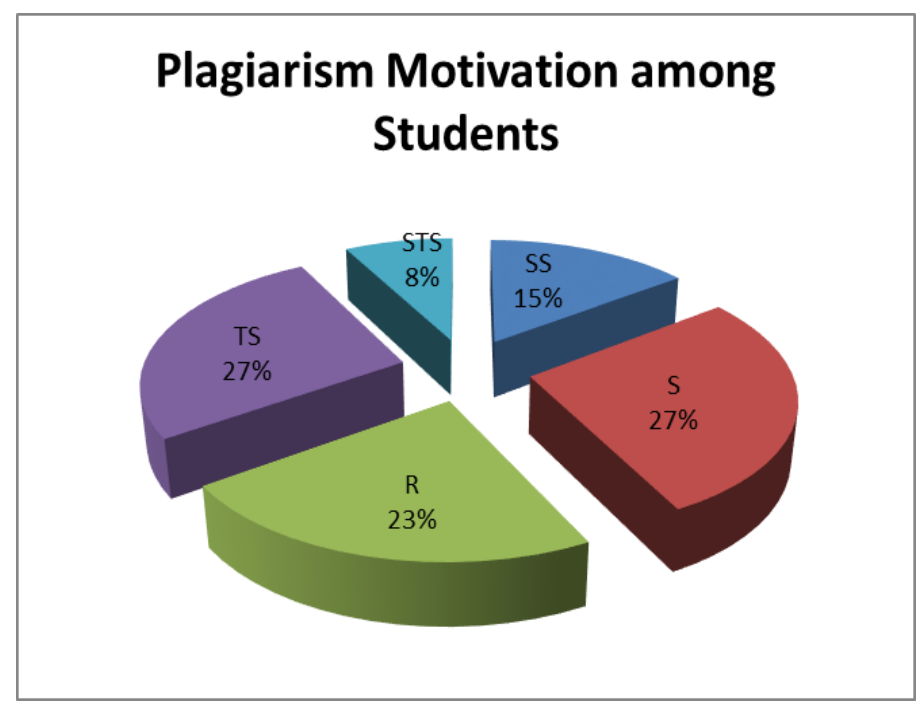

Figure 2. Results of plagiarism statement motivation among students

\section{c. Socialization Media for Early Prevention of Plagiarism}

Table 5: Socialization Media

\begin{tabular}{|l|l|l|}
\hline NO & Kinds of Media & Item \\
\hline 1 & Pamphlets, Books, Boards & 1,3 \\
\hline 2 & Lectures, in teaching and learning process & 2 \\
\hline
\end{tabular}

Based on Table 5 above, it can be described in three items statements. The statements were formulated to determine what media can be used to provide insight to students about the act of plagiarism is prohibited and contrary to legislation. The results of the questionnaire distribution as follows:

Tabel 6: Sosialisation Media (\%)

\begin{tabular}{|c|c|c|c|c|c|c|}
\hline \multirow[t]{2}{*}{ NO } & \multirow[t]{2}{*}{ Statements on Media } & \multicolumn{5}{|c|}{ Percentage } \\
\hline & & SS & $\mathbf{S}$ & $\mathbf{R}$ & TS & STS \\
\hline 1. & $\begin{array}{l}\text { Universities should set limits on the ethics of writing, } \\
\text { editing and others }\end{array}$ & 29 & 61 & 7 & 2 & 1 \\
\hline 2. & $\begin{array}{l}\text { Socialization ethics of writing, quite delivered } \\
\text { lecturers through messages at every meeting lecture }\end{array}$ & 26 & 37 & 9 & 20 & 8 \\
\hline 3. & $\begin{array}{l}\text { Noticeboard more effective in spreading the ethic of } \\
\text { writing freely than guidebooks }\end{array}$ & 19 & 44 & 12 & 21 & 4 \\
\hline
\end{tabular}

SS = Strongly Agree, $\mathrm{S}=$ Agree, R = Doubtful, TS = Disagree, STS = Strongly Disagree

According to the table above media statement, then the value of the average for the category agree was $48 \%$.

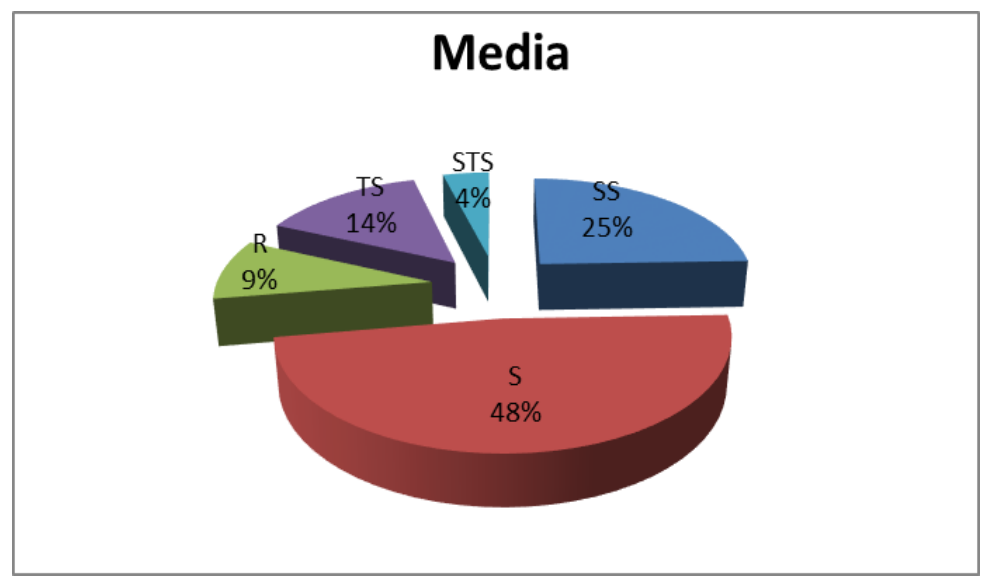

Figure 3 Result of Media Statement 


\section{The legal efforts Done by Faculty of Law, Muhammadiyah University of North Sumatra for early prevention of plagiarist student thesis.}

As an educational institution that is dynamic and progressive in establishing the truth and uphold the values of honesty, Muhammadiyah University of North Sumatra, obliged to ensure the scientific works, including works of research and authorship academic community does not violate the ethics of research and authorship of general application, which must meet the rules of science, and conducted based on conscience, morality, honesty, freedom, and responsibility, as well as good deed.

Based on documentation study conducted, that there had been a thesis writing guidelines issued by Faculty of Law, Muhammadiyah University of North Sumatra. But the manual just set:

a. preparation procedures;

b. thesis proposal and report format;

c. seminar participation requirements;

d. supervisor requirements;

e. syntax of writing;

f. format, systematics and procedures for conveying scientific publications.

Observing this phenomenon, illustrated that the law school believing that all students have the knowledge and commitment of plagiarism. That means students of the Faculty of Law, Muhammadiyah University of North Sumatra considered already know about quoting ideas, words, paragraphs and paraphrases. So also on the ethics of science in reading the works of others, and used as inspiration in writing his own works as well as how the data is considered valid research that filled the corridor as the authenticity of its own research data or data that is directly taken by researchers to the field.In addition, there has been a positive commitment and intent of the program of study to provide insight and require students to follow the ethics of writing for a work cited. There are two elements that researchers noted here, namely 1) writing a bibliography and 2) quotations. Procedures for and instructions for writing a bibliography and write citations described in the guidebook thesis, namely:

\section{References}

Preparation of bibliography diverse, but most importantly that the bibliography contains only the libraries contained in the thesis. Bibliography compiled down alphabetically by first author name (alphabetically). Titles and positions the author / authors do not need to be included. Notice how the writing if different types of libraries.

1) The authors consisting of 1 (one) and 2 (two) people, the way of writing: Name of the author. Year. Title of book (in italics). Publisher: City publisher.

2) The author of more than 2 (two) people, the way of writing; The first author's name followed by et al. or et. al. Year. Title of book (in italics). Publisher: City publisher.

Example:

Andi Hamzah. 1986. Perlindungan Hak-Hak Asasi Manusia dalam Kitab

Undang-Undang Hukum Acara Pidana. Bandung: Binacipta.

Soerjono Soekamto dan Sri Mamudji.1995. Penelitian Hukum Normatif Suatu Tinjauan Singkat. Jakarta: Raja Grafindo Persada.

Allan C. Moris, et al. 1995. College English New York: Social Science Research Council.

3) If the magazine is written: the author's name as in the book, with the title composition mediated quotation marks ("), the name of the magazine, the magazine number, month and year of publication. Example:

Bagir Manan."Hakim dan Pemidanaan".Dalam Majalah Varia Peradilan No. 249. Agustus 2006. 
4) If the paper is written: the author's name, title of the article is mediated quotation marks ("). Name of newspaper writing slant, date, month, and year of publication.

Example:

Budi Arif, "Upah minimum Untuk Siapa?". Artikel . Harian Waspada. Jum’at, 1 Nopembre 2013

5) If the essay was not published as theses, dissertations, papers, working papers, reports and other written: the author's name, year made, headline writing, types of writing (accompanied or others), for whatever use, the institution where the writing was made and the name of the town.

Example:

Atikah Rahmi. 2009. "Kajian Hukum Terhadap Aborsi Akibat Korban Perkosaan Kaitannya dengan Hak Asasi Manusia".Tesis.Program Pascasarjana. Program Magister Ilmu Hukum Universitas Muhammadiyah Sumatera Utara. Medan

Agus Purwadianto. 2003. "Perkosaan Sebagai Pelanggaran Hak Asasi Manusia (Kajian Filosofis Metodologi Pembuktian Hukum)"”, Disertasi. Program Studi Ilmu Filsafat Program Pascasarjana Fakultas Ilmu Pengetahuan Budaya Universitas Indonesia, Jakarta.

Sumapraja. 1 April 2000."Aborsi Ditinjau dari Sudut Hukum”, makalah, disampaikan dalam symposium mengenai Aborsi di Indonesia. Jakarta: Fakultas Hukum UI.

6) If the source of the internet is written; the author's name, title in quotation marks, sites using italics, day, date, month, year and hour accessible.

Example:

Budi, "Korban Perkosaan Sekarang Hamil",http://www.alt-cultureIndonesia.com, diakses senin, 25 Juli 2013.Pukul 23.00 WIB.

7) If the composition in an encyclopedia or the like written the author's name (if any specified), the title of the article, the name and the year of the encyclopedia.

Example:

Tim Penyusun Kamus Pusat Pembinaan dan Pengembanga. n Bahasa.1995. Kamus

Besar Bahasa Indonesia. Edisi Kedua, Jakarta: Balai Pustaka

\section{Quotations}

Quotations are borrowed someone's opinion taken either from books, journals, scientific papers were not published, magazines, newspapers, as well as interviews. Based on the type, consisting of excerpts:

1) Direct quotation, ie borrowing by taking the opinion of the full word by word, sentence by sentence of an original text and interviews. At the time of making a direct quotation, hence the quotes (authors) should not change the original text quoted. If the author felt the need to make changes, then it must provide bold or give brackets. If there are errors in the citation or peculiarity, the writer is not justified to correct these errors, but must cite as their. 
Authors are allowed to make repairs by using footnotes. If the omitted part of a quotation, the removal shall be stated by way of affixing eliplis (ie with three dots). As a note; removal of part citations may not result in changes to the original meaning of the text quoted.

The way of quotation can be done like these:

a). Direct quotation is less than 4 (four) lines. How to write a direct quote that is less than and / or equal to 4 (four) lines, are:

(1) Quotations are integrated with the text.

(2) The distance between rows with rows of two (2) spaces.

(3) Quotations are enclosed in quotes.

(4) End of quote consecutively numbered designation half spaced typed up. The serial number of citations can apply per-chapter but can also apply to the whole.

b). Direct quotes of more than four (4) lines. Direct quotations that exceed four (4) line, written in the following way:

(1) Quotations from the manuscript separated by a distance of three (3) spaces.

(2) The distance between the lines with the line is one (1) space.

(3) The quote does not need to be enclosed in quotes.

(4) End of quote consecutively numbered designation half spaced typed up.

(5) All quotations typed protrudes into seven (7) beats.

c). Indirect quotation, is to borrow someone's opinion in the form of essence or summary of the opinion. In the indirect quote, the author does not cite the script entirely. But just taking the essence of the article.

How to write the indirect quotes are:

(1) Quotations are integrated with the text.

(2) The distance between rows with row two spaces.

(3) The quote does not need to be enclosed in quotes.

(4) At the end of the citations consecutively numbered designation half spaced typed up.

(d) Quoting system. Authors who cite the opinions of others must credit the source citation is concerned. There are several ways of writing a quote sources, among others:

a) Chaniago Manual of Style (Kate L. Turabin). The way of writing by providing a number at the end of a quote, then the source is written on the bottom of the page that begins with the writing of numbers in accordance with the number of citations. Model writing of this quote often referred to as a footnote (footnotes system).

b) American Psychological Association Manual (APA). Writing model of this quote by stating directly the source end quote written in parentheses. This system is often referred to as endnotes (endnotes system).

Example:

(Suhrawardi K Lubis, 1995: 92).

c) Modem Language Associations Handbook (MLA). At the end of each citation given a number, then the source of the quotation at the end of chapters written on a special sheet called "records". How to write a quote sources such as the footnote.

Example:

Suhrawardi K Lubis. 1995. Hukum Waris Islam (Lengkap \& Praktis). Jakarta: Sinar Grafika, halaman 92.

2) System citing used in the Faculty of Law, Muhammadiyah University of North Sumatra, uses a system of footnote (footnotes system) or Chaniago Manual of Style. How footnote citation system is done by marking numbers or symbols on the text on the composition. Furthermore, on the bottom of the same page listed the reference source.

Footnote is a description of the text that is placed at the foot of the page composition question. In addition, the footnotes may also be used to provide other details of the text. Because the footnote and part of the text that will be given an explanation that there is a very close relationship. The relationship between footnotes and text to be explained is usually expressed with the same designation numbers, both contained within the body of the composition or referral source..

3) Footnote. Techniques to make a footnote is:

a) Make a long horizontal straight line 14 (fourteen) beats and put on the foot of the page no more than $3 \mathrm{~cm}$ from the bottom margin.

b) Number designation quote begins after seven (7) beats of the left margin, and the next row should start from the left margin.

c) The distance between the rows in the footnote is 1 (one) space, while the distance between the footnotes to the footnotes of other on the same page is two (2) spaces. 
d) Each footnote to be numbered for the entire script, located upstairs and word / phrase next to the tap to - 6 (parallel to the new paragraph). Next, if more than one row back to the base boundary by a distance of 1 typing dikiri spaces.

e) The last part of the footnote should be fitted at the boundaries of typing (margin) down on paper.

f) In the footnotes can be used abbreviations like:

(1) Ibid., Used if the next quote is taken from the same source as the source of the previous quote without mediated by citations and other sources. The term is derived from other words Ibidem meaning at the same place. This abbreviation is used if the footnote refers to works or articles that have been previously mentioned in the account number. If a different page, then used the abbreviation ibid., Writing followed by punctuation., And italics. Example: ibid., Page 7 (if different sources page).

(2) Op., Cit., Used if the page cited were different. This abbreviation is used if the record was reappointed sources that have been mentioned first, but the next quote is taken from the same source as the source of a previously existing quote or in other words, the quotation was taken but already mediated / interrupted by quotations and other sources. This abbreviation is derived from other words Opere Citato meaning in the works cited. The way of writing; by stating the author's name and then stands op. cit., Sunardi example, op. cit., page 4.

(3) Loc. Cit., dipakai jika halaman yang dikutip dan sumbernya itu sama. Singkatan ini berasal dari bahasa latin loco citato yang artinya pada tempat yang telah dikutip. Singkatan ini biasanya dipakai untuk menunjuk kepada artikel majalah, harian atau ensikopedi yang telah dibuat sebelumnya tetapi diselingi oleh sumber lainnya. Contoh Sunardi, loc. cit.

As for which is a must for study programs to give signs of firmness, after students are given instructions on citing rules that meet the ethics of science. Some restrictions or prohibitions according to the researchers, which should be written in essay writing handbook are:

1) copy of a raw paper without citing sources. Included in this category one when plagiarism is done more than $50 \%$ of the original text. In this category many parts of the original paper is copied with no reference at all.

2) slavishly copying portions still great without citing sources.

3) copying some elements of writing such as paragraphs, sentences, images or tables without citing sources.

4) the rewriting of a page or a paragraph without mentioning the original reference. Some words or phrases can be changed order, but without any mention of the original source still called plagiarism.

5 ) if the copied text has been naming its sources, but way less true disclosure. For example do not put quotation marks around the phrase that the original text is not altered, or copying sentences by simply changing the sequence or just change the number of words.

6) refer to the source clearly.

7) if quoting exactly granted do not forget the quotes.

8) the passage quoted can be rewritten again with different ways of expressing but keep the same meaning.

This does not mean we just flipping wording or simply replace with other words that have same meaning.

Furthermore, the consequences of which contain forms of sanctions, is also not regulated like strikes, liability for damages of material, suspension, termination, dismissal as a student..

\section{CONCLUSION}

Plagiarism is an act of insult to the academic world. However difficult, everyone must be united and determined in combating plagiarism. The phenomenon of plagiarism is widespread also in the Faculty of Law, University of Muhammadiyah North Sumatra. It can be said, the occurrence of plagiarism among students is not merely for dishonesty, but there are several reasons that can be classified to two (2) factors, namely internal and external factors. Internal factors include; their idleness in ourselves, anxiety, pressure / stress, fear of failure, pessimism toward self-efficacy, and felt the act was not a thing wrong and harmful, and have confidence that the behavior is not known.Meanwhile, external factors that cause the occurrence of plagiarism among others, permissiveness of the environment on the behavior of plagiarism, is less sensitive to the symptoms of the underlying causes of the behavior of plagiarism, the attitude is not expressly institutions to sanctions given to the behavior of plagiarism, the tendency to cover cases of plagiarism because of fear of negative imagery in the institution.

\section{REFERENCES}

[1]. Ali, Marpuji. (2000). Pola Pengembangan Kemahasiswaan. Solo.

[2]. Brotowidjoyo, M.D. (1993). Penulisan Karangan Ilmiah. Edisi Kedua. Jakarta: Akademika Pressindo.

[3]. Echols, J.M. dan H, Shadily. (1983). Kamus Inggris Indonesia. Jakarta: P.T. Gramedia.

[4]. Heffernan, J.A.W and J.E. Lincoln. (1986). Writing, A College Handbook. Second Edition. New York -London, W.W. Norton \& Company.

[5]. Ismail, Taufiq. (2006). "Pencucian Citra SDM Warisan Kolonial, Peletakan Paradigma SDM Baru; Mungkinkah"? Yogyakarta: Naskah Pidato Dies Natalis UNY. 
[6]. Juhanaini. (2011). "Research and Development. Metodep Penelitian dan Pengembangan".http://file.upi. edu/Direktori/ FIP/JUR._PEND._LUAR_BIASA/196005051986032JUHANAINI/Presentasi_Research_and_Development.pdf, diakses tanggal 2 November 2015.

[7]. Republik Indonesia. (2010). Peraturan Menteri Pendidikan Nasional Nomor 17 Tahun 2010 tentang Pencegahan dan Penanggulangan Plagiat Di Perguruan Tinggi.

[8]. Rachmad, Edy. (2010). 'Fenomena Plagiarisme di Kampus". Jurnal Waspada. Medan.

[9]. Soelistyo, H. (2011). Plagiarisme: Pelanggaran Hak Cipta dan Etika. Yogyakarta: Kanisius.

[10]. Sugiyono. (2009). Pengertian Teknik Sampling. Bandung: Alfabeta.

[11]. Tilar, H.A.R. (1998). Beberapa Agenda Reformasi Pendidikan Nasional. Indonesia: Tera.

[12]. Utorodewo, Felicia, dkk. (2007). Bahasa Indonesia: Sebuah Pengantar Penulisan Ilmiah. Jakarta: Lembaga Penerbit FEUI.

[13]. Universitas Negeri Yogyakarta. (2005). Peraturan Akademik UNY. 